\title{
The Role of Empathy in Experiential Learning: A Case Study of Empathy as an Interior Design Learning Tool
}

\author{
Lilia Gomez-Lanier ${ }^{1}$ \\ ${ }^{1}$ Assistant Professor, Department of Textiles, Merchandising and Interiors, University of Georgia, United States \\ Correspondence: Lilia Gomez-Lanier, Assistant Professor, Department of Textiles, Merchandising and Interiors, \\ University of Georgia, United States.
}

Received: January 15,2018

doi:10.11114/ijsss.v6i4.3054

\author{
Accepted: February 8, $2018 \quad$ Available online: February 23, 2018
}

URL: https://doi.org/10.11114/ijsss.v6i4.3054

\begin{abstract}
Empathy definitions do not adequately reflect the realities of empathy in the context of interior design for the elderly or disabled. This mixed research methods study explored the role that empathy as a design learning tool may have on the design process and learning experiences of interior design students, whom ultimately will design spaces for the elderly and disabled. To explore the use of empathy as a learning tool prior to commencing a renovation design project for three disabled farmers and their families in the southeast area of the United States, interior design students participated in class exercises that simulated various physical disabilities. After completing the exercises students reported high levels of emphatic concern for physically disabled older adults that made them more in tuned with the program needs of their clients, the farmers. Additionally, the students acknowledged that they had gained a greater understanding of inclusive design, whereby all end users of spaces regardless of physical and mental capabilities are to be considered when designing interior environments. Lastly, students enhanced their problem-solving skills by gaining insights into the importance of considering all details in design, ranging from the addition of coat hooks to door hardware selection and floor finish materials to furniture placements. This study is significant because two of the fastest growing sectors for interior design is healthcare and aging in place.
\end{abstract}

Keywords: experiential learning, interior design, older adults, higher education

\section{Introduction}

\subsection{Introduce the Problem}

This study explored the role that empathy may have on the experiential learning of interior design students in a residential design studio. In particular, students' perceptions of the elderly and disabled, and the use of empathy as a learning tool for the design of interior spaces that accommodate elderly and disabled individuals. For professions that rely on building relationships, empathy is a key element in the professional relationship of service providers and their clients. In the case of interior design, this is particularly important because most practitioners procure design jobs from established, repeat clients and referrals. Having the ability to understand a client's design needs is paramount for interior designers to design spaces that physically and emotionally respond to the pragmatic design needs of each client. Research lends support for empathy in the workplace by suggesting that individuals who are better able to identify with the emotions of others are more successful in their work as well as their personal lives (Rosenthal, 1977; Bakker \& Demerouti, 2009; Grant, 2014). The structure of this paper follows the logic of the mixed research process. First, a review of relevant research guided the guided the development of the various class empathy exercises, the study's online survey instrument, design projects and reflection papers. Lastly, the research study's findings are presented. The discussion of these findings leads to the outline of future research and perspectives on the use of empathy as a learning tool for interior design students and others that work with diverse individuals or wish to create inclusive environments.

\subsection{Explore the Importance of the Problem}

According to the U.S. Census Bureau (2016), by the year 2050, one out of five individuals in the U.S. will be over 65 years of age. Furthermore, according to an American Society of Interior Designers (ASID) 2014 report, the majority of the U.S.'s aging population wishes to remain living in their homes as they age in place, which suggests growing design opportunities for residential interior designers. Along with these changing demographics come design issues concerning diminishing physical and mental capacities of individuals, as well as lifestyle and personal characteristics. With these 
changes projected to occur for the next 30 years and more, it is important that interior design students be prepared to understand the emotional and programmatic demands of elderly and disabled individuals. This study is significant because it brings forth evidence that interior design students require support to develop emphatic skills that will assist them in their future workplace.

\subsection{Literature Review}

\subsubsection{Empathy}

Empathy as defined by Strayer (1987) is "feeling in oneself the feeling of others" (p. 391). Literature review suggests that discussions on the topic of empathy are occurring across disciplines from psychoanalysts to humanism and social work to anthropology (Strayer, 1987; Batson, Polycarpou, Harmon-Jones, Imhoff, Mitchener, Bednar, Klein, \& Highberger, 1997). Such a broad interest in empathy supports the notion that it is fundamental for individuals to have the ability to be empathetic toward others when forming and fostering human relationships (Omdahl, 1995; Batson, Turk, Shaw, \& Klein, 1995; Wang, Davidson, Yakushko, Bielstein Savoy, Tan, \& Bleier, 2003).

\subsubsection{Cultural Empathy}

Service industries, such as interior design, work with clients from all lifestyles, which is why it is important to expand the definition of empathy to include culture. Ridley and Lingle (1996) defined cultural empathy as a learned ability that allows individuals to understand the experiences of clients from culturally diverse backgrounds. Although individuals may primarily view cultural empathy in terms of national cultures, cultural empathy also applies to sub-groups of individuals within the larger context of society, such as the elderly and disabled. Tervo, Azuma, Palmer, and Redinius (2002) showed evidence that prevailing attitudes and misconceptions of individuals is influenced by demographic variables such as age, gender, socioeconomic status, and the like. Tervo et al (2002) also indicated that negative attitudes toward disabled indi viduals are a product of a person's belief system and society's practices. Yuker, Block, and Campbell (1960) discovered that American college students had a more favorable perception toward individuals that are blind than French college students. Furthermore, Jacques, Linkowski, and Sieka (1970) explored attitudes toward individuals with disabilities in the United States, Greece and Denmark. Their research discovered that individuals in the United States were the most positive toward disabled individuals, while the Greeks were the least favorable. These studies bring to light that ethnocentricity is part of the cultural empathy discussion.

\subsubsection{Empathetic Modeling}

Empathic modeling is experiencing with your own body the physical situations of others (Thomas \& McDonagh, 2013). As a learning strategy, empathetic modeling assists individuals in expanding their empathetic lens by gaining an understanding of another person's point of view and establishing an emotional connection with that other person (Thomas \& McDonagh, 2013). The researchers further suggested that because individuals approach others with their own assumptions and preconceptions, empathetic modeling pushes individuals outside of their comfort zones to enhance understanding their own values and beliefs. In turn, this simulation of what others physically experience leads individuals to be less willing to project their own perceptions onto others (Thomas \& McDonagh, 2013).

\section{Method}

In an effort to understand, the depth and breadth empathy plays in interior design learning this study reviewed student perceptions through the lens of quantitative and qualitative data. The research study explored two underlying research hypotheses that revolved around empathy as a learning tool. The research hypothesis is articulated as follows:

1. Hypothesis 1: Empathy as a learning tool enhances problem solving skills of interior design students so as to look at projects in more comprehensive terms.

2. Hypothesis 2: Empathy nurtures an inclusive design approach in interior design students.

The study's mixed method adds a richer understanding of client needs and their particular built environment needs.

\subsection{Participants}

Empathy is brought forth to an upper-level residential interior design studio course of a four-year undergraduate interior design program in a large public uni versity in the southeast area of the United States. The course consisted of eleven interior design students, who all volunteered to participate in this study. However, only ten students completed the preand post-project surveys. All of the ten participants were females, and upon graduation, all intend to work as interior designers. With the exception of one participant who was in her forties, the remaining participants were between the ages of 22 and 25 years old. The instructor, who is also the author, provided students with three experiential learning assignments that incorporated empathy as a learning tool. 


\subsection{Quantitative Phase}

This design study used descriptive statistical analysis to perform the analysis of pre-and post-design project surveys. The 30 closed ended questions survey developed by Yuker, Block and Young (1960) concentrates on two types of concerns: the characteristics of disabled individuals and the treatment and needs of persons with disabilities (Yuker et al., 1960). Although eleven students volunteered to participate in the study and received extra credit toward their class grade, in the end one participant did not complete both surveys and one participant completed the surveys with the exception of responding to questions 10 and 28 on either survey. Thus, responses to those particular questions are not included in the findings.

\subsection{Qualitative Phase}

\subsubsection{Assignments and Design Process}

The duration of each of the three design assignments varied depending on the scope of work required. The three assignments covered research, understanding, application and implementation of design skills and ideas empathy as a learning tool (See Figure 1). Assignment 1 dealt with maintaining a design journal throughout the semester that researched and deciphered various interior spaces used and their occupants. Assignment 2 pertained to completing an empathetic modeling assignment that challenged students to understand and feel what disabled individuals experience when performing common daily activities. Assignment 3 pertained to de veloping construction drawings for the renovation of three homes occupied by disabled farmers.

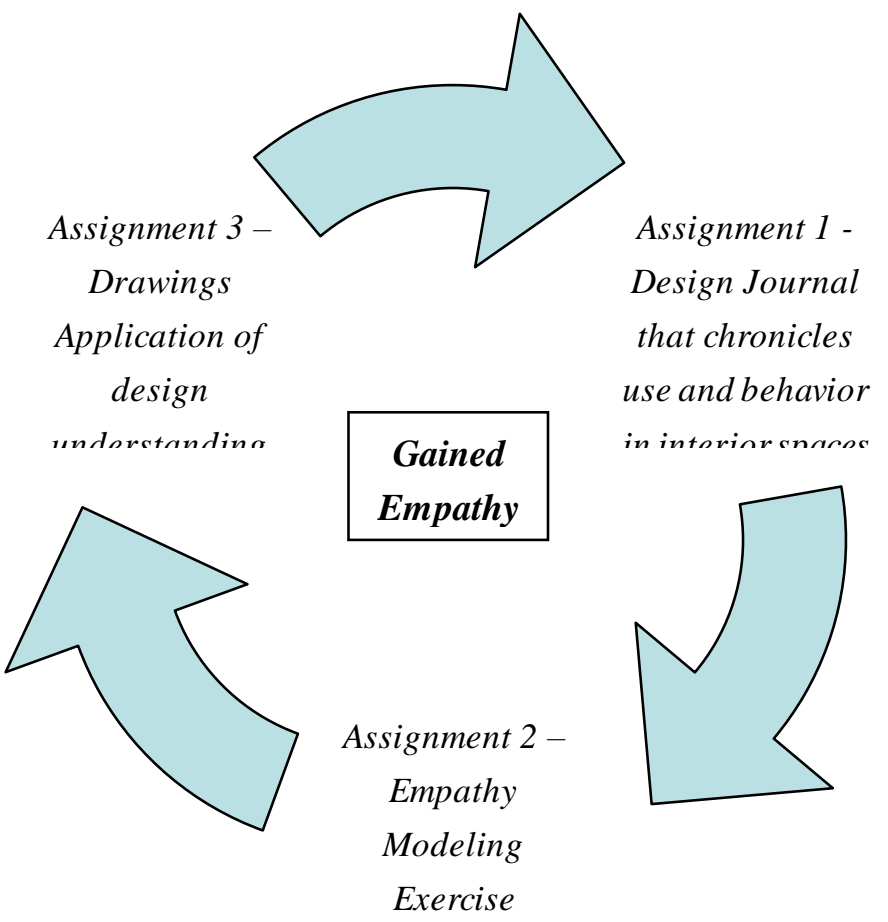

Figure 1. Design Process

\subsubsection{Assignment 1 - Observation Journal}

The design journal objective was to have students refine their observational and analytical skills of interior spaces used on a daily basis or frequently. Even though the studio's focus was residential, students observed their own home as well as five commercial establishments because individuals also frequent on a daily basis other occupancy types that affect lifestyle, activities and behaviors of the individuals using those spaces. Students observed each space at two different times during the day and on two different weekdays. In particular the observation of access/egress points, accessibility, circulation paths, types and use of furniture, space plan, privacy, human behavior, lighting, architectural elements and finishes. Along with written summaries of their observational experiences, students were required to have free-hand sketches of the interior spaces.

\subsubsection{Assignment 2 - Emphatic Modeling}

This phase, which lasted one studio session, was an emphatic modeling assignment compost of three phases: experiential learning activity, verbal reflection and written reflection. The assignment pertained to five student teams 
experiencing several of the physical disabilities commonly experienced by the elderly, while also performing several daily tasks that an elderly and disabled individual would. Students were blindfolded to mimic the loss of sight. To simulate loss of mobility, students used crutches, wheelchairs or walkers while wearing 10-pound ankle weights. To simulate arthritis, students wore gloves with socks or wooden craft sticks inside. To simulate hearing loss, students wore earplugs. Students performed the various tasks while experiencing the simulation of three disabilities at a time. The following represents the various tasks completed by the students:

1. Open the classroom door to the hall without any assistance, while observing the measurements needed on either side of the door to exit to the hall.

2. Enter the small computer lab, sitting at a computer terminal, and try to type four sentences, and then exiting the room.

3. Enter one of the studios and directing themselves to a table. Using the table for a few minutes - pulling themselves under the table, reaching and using objects nearby.

4. Going out of the studio and proceed to the printer and locker room. Going through the door and opening a locker.

5. Attempt to purchase an item from the vending machine in the building.

6. Go to the restroom and transfer to the handicap stall using only the grab bars. Use the sink prior to leaving the bathroom.

7. Go outside the building, down the ramp and use the sidewalk for a short distance. After using a portion of the sidewalk, re-enter the building going up the ramp.

8. Walk up and down the exterior stairs leading to the parking lot.

9. Re-enter the classroom.

After the students completed the tasks, the class discussed students' experiences and by the next class submitted a two-page minimum reflection paper.

\subsubsection{Assignment 3 - Design Project}

The design project, a residential renovation for three local farming families that live within an hour's drive of the university campus, came about from a request for assistance by a university program that specializes in assisting local disabled farmers to continue farming. The program's director contacted the author requesting assistance with proposing home renovation ideas for three local farming families. Even though the three homes were well maintained and livable, none of the existing house layouts allowed the elderly and disabled occupants, the husbands, to perform daily functions with ease, such as bathing and cooking. Therefore, limiting the farmers' quality of life and preventing them from fully carrying out their work responsibilities. Farmer household 1 was composed of a middle-aged couple where the husband is as an amputee that uses a prosthetic leg and wheelchair to move about. Farmer household 2 consisted of an elderly couple of which the husband is in the early stages of Parkinson disease. Farmer household 3 pertained to an elderly couple of which the husband is paralyzed from the waist down from a spinal cord injury.

Because of the scope of work, students worked in teams of two to three students. Although the five student teams were randomly assigned one of the three farming family homes, two households had two student design teams. The design assignment consisted of two phases: Part A, a program analysis; and Part B, design construction drawings.

For Part A, students interviewed their respective families in order to understand their clients' unique characteristics and programmatic needs. Unfortunately, during Part A, Households 1 and 2 became unable to meet with their students due to their illness. Even though time constraints prevented students from traveling to these households later, a representative for the university's farmer assistance program interviewed, photographed and provided preliminary house drawings of farmer households 1 and 2. Thus, student teams were only able to conduct a face-to-face interview and tour household 3. While interviewing household 3, students documented the physical conditions of the home by physically measuring spaces and photographing the existing conditions, key tasks that practitioners conduct.

For Part B, student teams developed designs and construction drawing sets for their assigned families based on client data, universal design principles and a construction budget provided by the university's farmer assistance program. At the conclusion of Part B, student teams formally presented their designs to the three families and the university's farmer assistance program. The author, in the role of instructor, over the course of the design project provided informal critiques of student work. In addition to receiving instructional feedback every class, students and the instructor discussed design reasoning. Furthermore, the researcher as instructor frequently marked-up drawings and returned them to the students. 


\section{Results}

\subsection{Quantitative Statistics and Analysis}

The more disabled individuals are perceived as being different, the more negative the participants' attitudes. Conversely, lower scores indicate positive attitudes toward disabled individuals (Table 1). The findings suggested that students gained a slightly more favorable perception of disabled individuals as the design project progressed. However, there were certain questions that did prompt a stronger positive view of disabled individuals. For instances, post-project responses indicated that students moved toward strongly disagreeing with question 20 , which pertained to disabled persons resenting physically able individuals. For question 22, at the beginning of the project, students indicated a neutral view on disabled persons being able to take care of themselves, yet over the course of the project, students gained a positive outlook on whether the disabled would be able to take care of themselves. Question 25 asked students if disabled persons were less self-confident than others were; the students moved from neutral toward strongly disagreeing with the question. Furthermore, for question 29, students moved from agreeing toward strongly agreeing that the disabled do not want any more sympathy than other people do. While for question 30 on whether the manner in which disabled persons act is irritating, students moved from strongly disagreeing to an even stronger disagreeing stance.

The quantitative findings further indicate that over the course of working on the design project, the students gained an even more favorable perception of disabled individuals. Whether participating in the face-to-face client interview, touring the client's home or completing the design observation journal, had equal or greater influence on the post survey outcomes while problem solving the design project is debatable. However, it is clear that the combination of these activities did favorably influence the empathetic understanding of students.

Table 1. Descriptive Statistical Analysis

\begin{tabular}{|c|c|c|c|c|c|c|c|}
\hline Type of Survey & & Survey Question & $\mathrm{N}$ & Minimum & Maximum & Mean & Std. Deviation \\
\hline Pre-project & 1. & Disabled people are often unfriendly & 10 & 2.00 & 5.00 & 3.7000 & .94868 \\
\hline Post-project & 1. & Disabled people are often unfriendly & 10 & 2.00 & 5.00 & 4.0000 & 1.05409 \\
\hline Pre-project & 2. & $\begin{array}{l}\text { Disabled people should not have to } \\
\text { compete for jobs with physically } \\
\text { normal persons }\end{array}$ & 10 & 1.00 & 4.00 & 3.3000 & .94868 \\
\hline Post-project & 2. & $\begin{array}{l}\text { Disabled people should not have to } \\
\text { compete for jobs with physically } \\
\text { normal persons }\end{array}$ & 10 & 2.00 & 5.00 & 3.2000 & 1.03280 \\
\hline Pre-project & 3. & $\begin{array}{l}\text { Disabled people are more emotional } \\
\text { than other people }\end{array}$ & 10 & 2.00 & 5.00 & 3.3000 & 1.05935 \\
\hline Post-project & 3. & $\begin{array}{l}\text { Disabled people are more emotional } \\
\text { than other people }\end{array}$ & 10 & 3.00 & 5.00 & 3.9000 & .73786 \\
\hline Pre-project & 4. & $\begin{array}{l}\text { Most disabled persons are more } \\
\text { self-conscious than other people }\end{array}$ & 10 & 1.00 & 5.00 & 2.5000 & 1.08012 \\
\hline Post-project & 4. & $\begin{array}{l}\text { Most disabled persons are more } \\
\text { self-conscious than other people }\end{array}$ & 10 & 1.00 & 5.00 & 3.4000 & 1.26491 \\
\hline Pre-project & 5. & $\begin{array}{l}\text { We should expect just as much from } \\
\text { disabled as from non-disabled } \\
\text { persons }\end{array}$ & 10 & 1.00 & 4.00 & 2.7000 & 1.05935 \\
\hline Post-project & 5. & $\begin{array}{l}\text { We should expect just as much from } \\
\text { disabled as from non-disabled } \\
\text { persons }\end{array}$ & 10 & 1.00 & 4.00 & 2.5000 & 1.26930 \\
\hline Pre-project & 6. & $\begin{array}{l}\text { Disabled workers cannot be } \\
\text { as successfulas other workers }\end{array}$ & 10 & 3.00 & 5.00 & 4.3000 & .67495 \\
\hline Post-project & 6. & $\begin{array}{l}\text { Disabled workers cannot be } \\
\text { as successfulas other workers }\end{array}$ & 10 & 3.00 & 5.00 & 4.4000 & 69921 \\
\hline Pre-project & 7. & $\begin{array}{l}\text { Disabled people usually do not make } \\
\text { much of a contribution to society }\end{array}$ & 10 & 4.00 & 5.00 & 4.4000 & .51640 \\
\hline Post-project & 7. & $\begin{array}{l}\text { Disabled people usually do not make } \\
\text { much of a contribution to society }\end{array}$ & 10 & 3.00 & 5.00 & 4.6000 & 69921 \\
\hline Pre-project & 8. & $\begin{array}{l}\text { Most non-disabled people would not } \\
\text { want to marry anyone who is } \\
\text { physically disabled }\end{array}$ & 10 & 2.00 & 5.00 & 3.3000 & 1.05935 \\
\hline Post-project & 8. & $\begin{array}{l}\text { Most non-disabled people would not } \\
\text { want to marry anyone who is } \\
\text { physically disabled }\end{array}$ & 10 & 2.00 & 5.00 & 3.5000 & .97183 \\
\hline Pre-project & 9. & $\begin{array}{l}\text { Disabled people show as much } \\
\text { enthusiasmas otherpeople }\end{array}$ & 10 & 1.00 & 5.00 & 2.7000 & 1.25167 \\
\hline
\end{tabular}




\begin{tabular}{|c|c|c|c|c|c|c|c|}
\hline Type of Survey & & Survey Question & $\mathrm{N}$ & Minimum & Maximum & Mean & Std. Deviation \\
\hline Post-project & 9. & $\begin{array}{l}\text { Disabled people show as much } \\
\text { enthusiasmas other people }\end{array}$ & 10 & 1.00 & 4.00 & 2.1000 & .99443 \\
\hline Pre-project & 10. & $\begin{array}{l}\text { Disabled persons are usually more } \\
\text { sensitive than other people }\end{array}$ & & $\begin{array}{l}\text { Only } 9 \text { students } \\
\text { answered this } \\
\text { question }\end{array}$ & & & \\
\hline Post-project & 10. & $\begin{array}{l}\text { Disabled persons are usually more } \\
\text { sensitive than other people }\end{array}$ & & $\begin{array}{l}\text { Only } 9 \text { students } \\
\text { answered this } \\
\text { question }\end{array}$ & & & \\
\hline Pre-project & 11. & $\begin{array}{l}\text { Severely disabled persons are } \\
\text { usually untidy }\end{array}$ & 10 & 2.00 & 5.00 & 3.0000 & .94281 \\
\hline Post-project & 11. & $\begin{array}{l}\text { Severely disabled persons are } \\
\text { usually untidy }\end{array}$ & 10 & 2.00 & 5.00 & 3.3000 & 1.05935 \\
\hline Pre-project & 12. & $\begin{array}{l}\text { Most disabled people feel that } \\
\text { they are as good as other people }\end{array}$ & 10 & 3.00 & 5.00 & 3.2000 & .63246 \\
\hline Post-project & 12. & $\begin{array}{l}\text { Most disabled people feel that they } \\
\text { are as good as other people }\end{array}$ & 10 & 3.00 & 5.00 & 3.5000 & .70711 \\
\hline Pre-project & 13. & $\begin{array}{l}\text { The driving test given to a } \\
\text { disabled person should be more } \\
\text { severe than the one given to the } \\
\text { non-disabled }\end{array}$ & 10 & 2.00 & 5.00 & 3.6000 & .84327 \\
\hline Post-project & 13. & $\begin{array}{l}\text { The driving test given to a disabled } \\
\text { person should be more severe than } \\
\text { the one given to the non-disabled }\end{array}$ & 10 & 2.00 & 4.00 & 3.5000 & .70711 \\
\hline Pre-project & 14. & Disabled people are really sociable & 10 & 1.00 & 4.00 & 2.7000 & .82327 \\
\hline Post-project & 14. & Disabled people are really sociable & 10 & 1.00 & 4.00 & 2.6000 & 1.07497 \\
\hline Pre-project & 15. & $\begin{array}{l}\text { Disabled persons usually are } \\
\text { not as conscientious as physically } \\
\text { normal persons }\end{array}$ & 10 & 3.00 & 5.00 & 4.0000 & 66667 \\
\hline Post-project & 15. & $\begin{array}{l}\text { Disabled persons usually are } \\
\text { not as conscientious as } \\
\text { physically normal persons }\end{array}$ & 10 & 2.00 & 5.00 & 3.6000 & .96609 \\
\hline Pre-project & 16. & $\begin{array}{l}\text { Severely disabled persons probably } \\
\text { worry more about their health } \\
\text { than those who have minor } \\
\text { disabilities }\end{array}$ & 10 & 1.00 & 4.00 & 2.2000 & .91894 \\
\hline Post-project & 16. & $\begin{array}{l}\text { Severely disabled persons probably } \\
\text { worry more about their health } \\
\text { than those who have minor } \\
\text { disabilities }\end{array}$ & 10 & 1.00 & 5.00 & 2.3000 & 1.15950 \\
\hline Pre-project & 17. & $\begin{array}{l}\text { Most disabled persons are not } \\
\text { dissatisfied with themselves }\end{array}$ & 10 & 2.00 & 4.00 & 3.1000 & .73786 \\
\hline Post-project & 17. & $\begin{array}{l}\text { Most disabled persons are not } \\
\text { dissatisfied with themselves }\end{array}$ & 10 & 2.00 & 5.00 & 3.2000 & .91894 \\
\hline Pre-project & 18. & $\begin{array}{l}\text { There are more misfits among } \\
\text { disabled persons than among } \\
\text { non-disabled persons }\end{array}$ & 10 & 2.00 & 5.00 & 3.3000 & 1.05935 \\
\hline Post-project & 18. & $\begin{array}{l}\text { There are more misfits among } \\
\text { disabled persons than among } \\
\text { non-disabled persons }\end{array}$ & 10 & 2.00 & 5.00 & 3.8000 & .91894 \\
\hline Pre-project & 19. & $\begin{array}{l}\text { Most disabled persons do not get } \\
\text { discouraged easily }\end{array}$ & 10 & 2.00 & 4.00 & 3.3000 & .67495 \\
\hline Post-project & 19. & $\begin{array}{l}\text { Most disabled persons do not get } \\
\text { discouraged easily }\end{array}$ & 10 & 1.00 & 4.00 & 3.0000 & .94281 \\
\hline Pre-project & 20. & $\begin{array}{l}\text { Most disabled persons resent } \\
\text { physically normal people }\end{array}$ & 10 & 3.00 & 4.00 & 3.6000 & .51640 \\
\hline Post-project & 20. & $\begin{array}{l}\text { Most disabled persons resent } \\
\text { physically normal people }\end{array}$ & 10 & 3.00 & 5.00 & 4.1000 & .56765 \\
\hline Pre-project & 21. & $\begin{array}{l}\text { Disabled children should compete } \\
\text { with physically normal } \\
\text { children }\end{array}$ & 10 & 2.00 & 5.00 & 3.3000 & 1.05935 \\
\hline Post-project & 21. & $\begin{array}{l}\text { Disabled children should compete } \\
\text { with physically normal children }\end{array}$ & 10 & 2.00 & 5.00 & 2.9000 & 1.10050 \\
\hline Pre-project & 22. & $\begin{array}{l}\text { Most disabled persons can take care } \\
\text { of themselves }\end{array}$ & 10 & 2.00 & 4.00 & 3.2000 & .63246 \\
\hline Post-project & 22. & $\begin{array}{l}\text { Most disabled persons can take care } \\
\text { of themselves }\end{array}$ & 10 & 1.00 & 5.00 & 2.7000 & 1.15950 \\
\hline
\end{tabular}




\begin{tabular}{|c|c|c|c|c|c|c|c|}
\hline Type of Survey & & Survey Question & $\mathrm{N}$ & Minimum & Maximum & Mean & Std. Deviation \\
\hline Pre-project & 23. & $\begin{array}{l}\text { It would be best if disabled persons } \\
\text { would live and work with } \\
\text { non-disabled persons }\end{array}$ & 10 & 2.00 & 3.00 & 2.4000 & .51640 \\
\hline Post-project & 23. & $\begin{array}{l}\text { It would be best if disabled persons } \\
\text { would live and work with } \\
\text { non-disabled persons }\end{array}$ & 10 & 2.00 & 4.00 & 2.7000 & .82327 \\
\hline Pre-project & 24. & $\begin{array}{l}\text { Most severely disabled people are } \\
\text { just as ambitious as physically } \\
\text { normal persons }\end{array}$ & 10 & 1.00 & 3.00 & 2.1000 & .56765 \\
\hline Post-project & 24. & $\begin{array}{l}\text { Most severely disabled people are } \\
\text { just as ambitious as physically } \\
\text { normal persons }\end{array}$ & 10 & 1.00 & 4.00 & 2.2000 & 1.03280 \\
\hline Pre-project & 25. & $\begin{array}{l}\text { Disabled people are just as } \\
\text { self-confident as other people }\end{array}$ & 10 & 2.00 & 4.00 & 2.7000 & .82327 \\
\hline Post-project & 25. & $\begin{array}{l}\text { Disabled people are just as } \\
\text { self-confident as other people }\end{array}$ & 10 & 1.00 & 4.00 & 2.1000 & .99443 \\
\hline Pre-project & 26. & $\begin{array}{l}\text { Most disabled persons want more } \\
\text { affection and praise than other } \\
\text { people }\end{array}$ & 10 & 3.00 & 4.00 & 3.6000 & .51640 \\
\hline Post-project & 26. & $\begin{array}{l}\text { Most disabled persons want more } \\
\text { affection and praise than other } \\
\text { people }\end{array}$ & 10 & 3.00 & 5.00 & 3.8000 & .78881 \\
\hline Pre-project & 27. & $\begin{array}{l}\text { Physically disabled persons are often } \\
\text { less intelligent than non-disabled } \\
\text { people }\end{array}$ & 10 & 4.00 & 5.00 & 4.7000 & .48305 \\
\hline Post-project & 27. & $\begin{array}{l}\text { Physically disabled persons are often } \\
\text { less intelligent than non-disabled } \\
\text { people }\end{array}$ & 10 & 3.00 & 5.00 & 4.4000 & 69921 \\
\hline Pre-project & 28. & $\begin{array}{l}\text { Most disabled persons are } \\
\text { different from non-disabled }\end{array}$ & & $\begin{array}{l}\text { Only } 9 \text { students } \\
\text { answered this } \\
\text { question }\end{array}$ & & & \\
\hline Post-project & 28. & $\begin{array}{l}\text { Most disabled persons are different } \\
\text { from non-disabled }\end{array}$ & & $\begin{array}{l}\text { Only } 9 \text { students } \\
\text { answered this } \\
\text { question }\end{array}$ & & & \\
\hline Pre-project & 29. & $\begin{array}{l}\text { Disabled persons do not want any } \\
\text { more sympathy than other people }\end{array}$ & 10 & 1.00 & 4.00 & 2.4000 & 1.07497 \\
\hline Post-project & 29. & $\begin{array}{l}\text { Disabled persons do not want any } \\
\text { more sympathy than other people }\end{array}$ & 10 & 1.00 & 4.00 & 1.9000 & .99443 \\
\hline Pre-project & 30. & $\begin{array}{l}\text { The way disabled people act is } \\
\text { irritating }\end{array}$ & 10 & 2.00 & 5.00 & 4.1000 & .99443 \\
\hline Post-project & 30. & $\begin{array}{l}\text { The way disabled people act is } \\
\text { irritating }\end{array}$ & 10 & 3.00 & 5.00 & 4.4 & .69921 \\
\hline
\end{tabular}

\subsection{Qualitative Reflections}

\subsubsection{Assignment 1 - Observation Journal}

Findings suggested that over the course of the semester as students developed their design observation journals of interior spaces, students refined their abilities to see things that might have gone unnoticed before. The observation exercises revealed that students not only gained greater insights into how various interior spaces express identity, but also how they support human behavior and encourage activities. The students gained empathy for the inclusion of physically disabled individuals. The following represents a sample of student perceptions of the interior spaces observed:

Participant 1 after observing his or her own home stated, "As the furniture in my apartment is all cream beige colored, it is not ideal for the physically disabled in terms of depth perception. The furniture is not suitable for the disabled either because it is not firm enough. The home's aura changes from day to night. During the day, the home is bright, full of daylight, happy and young. While at night the home is comfortable, lazy and quiet."

Participant 2 after observing the activities and interior space of a local restaurant stated, "The circulation path from entry to counter, down the serving line and over to the drinks is evident and clear. Disabled individuals would have a hard time getting into the booth seating. However, there were plenty of tables for someone in a wheelchair to be able to easily roll up to and use".

Participant 3 during this assignment had a broken ankle, a foot boot and used crutches for several weeks. Thus, this participant lived the experience of being physically disabled. The following statements represent student's perceptions of their home: "The dorm has no elevators. The dorm is not easily accessible, so the first floor is 
the only floor accessible by the disabled. The exterior ramp and door openers are not conveniently located. The ramp was only added to the front of the building, so only one exit is available for disabled individuals rather than two. Seems like when designing the dorm minimal effort was done to help disabled individuals."

\subsubsection{Assignment 2 - Emphatic Modeling}

The emphatic modeling assignment findings showed a positive shift in student thinking of indi viduals with diminishing or limited physical capabilities. Through empathic modeling, students not only recognized the relevance of the assignment to their design project, but it also honed students' observational and problem-solving skills. Students observed features that designers of the building either omitted or did not fully address. The following represents a sampling of the perceptions of the two students that comprised Student Team 1:

Student Team 1 participant stated, "The most challenging aspect of navigating through the restroom was figuring out how to transition from the walker to the toilet seat. Experiencing hearing and visual impairments at the same time caused me to have issues with disorientation and balance. I think people as obstacles pose an equal threat to someone with disabilities than actual physical barriers. As interior designers it is our responsibility to make the world a safe place for all people especially for those with disabilities. "

Student Team 2 participant stated, "We had exceptional difficulty in the restroom. I could not get out of the wheelchair and onto the toilet seat using only grab bars. The stall's purse hook was inaccessible. As a designer, I would install two hooks at different heights to accommodate the disabled. I felt as though I was an inconvenience to the other person entering the restroom. This experience drastically changed my perception of what it is like to be disabled and the challenges that disabled people face on a regular basis. "

\subsubsection{Assignment 3 - Design Project}

Review and analysis of the design project solutions showed evidence of sensitivity to the unique circumstances of each of the three disabled farmers and their families. The design solutions not only addressed using universal design products for disabled individuals and building codes, but the solutions also adhered to the construction budget provided by the university's farmer assistance program. The following represents a sampling of the design project solutions:

Student Team 3 proposed designs for Household 1: Inspired by the family's sustainable farming practices, the team proposed sustainable products and materials throughout the home. The design proposed using universal design products such as kitchen upper cabinets that have pull down flex arm shelve. The shower was enlarged to accommodate a wheelchair, while a fold down shower seat was added. Locations of interior doors were relocated to make entry and circulation easier in the master suite. Grab bars were added to the master bathroom

Student Team 4 proposed designs for Household 2: The team's design goal was to make the home easy to use and accessible. The design took into consideration how quickly the husband's Parkinson disease may progress and prevent ease of mobility throughout the home. With the exception of the master bathroom, the floor plan remained unchanged because the existing plan was an open plan. Grab bars were added to the bathroom toilet and shower areas. Wood floors would replace existing carpet to allow for future wheelchair/walker movement. In addition, the toilet fixtures and kitchen/bathroom cabinets should be replaced with universal design compliant cabinets and appliances.

\section{Discussion}

The study showed that empathy could be a valuable tool in forming and changing the perceptions of students towards individuals that have disabilities. Both the quantitative and qualitative findings demonstrated that the use of empathy as a learning tool does influence the perceptions interior design students have toward the elderly and disabled individuals, while also enhancing the problem-solving skills and overall design approach of interior design students. The findings revealed that empathy does enhance the problem-solving design skills and fosters an inclusive design approach in interior design students. Phase 2, the empathetic modeling assignment, final drawing documents and reflection journals, demonstrated four distinct ways empathy influences problem solving design skills and inclusive designs.

Firstly, students realized that the small details of a space are as important as the large architectural elements, such as location of coat hooks compared to number of doors and windows. For instance, a student reported that they would install two coat hooks in the handicap toilet stalls for a person in a wheelchair to have easier access to personal items. Students became more observant of their own environments and introduced that knowledge into their design solutions.

Secondly, through the experience of the emphatic modeling exercises and first-hand observations the home of one of the disabled farmers, students gained an understanding of the design concept that individuals with physical limitations will manifest those limitations at different levels. For instance, the physical ability and experience of a wheelchair-bound 
person is different from the physical ability and experience of a blind person. Furthermore, students reported a deeper understanding of how the built environment, both interior and exterior, can affect an indi vidual's inclusion and ability to use the space. For example, the vending machine, although providing Braille, a blind person would still not be able to know the vending selections, while someone who is wheelchair bound will only be able to retrieve an item from the vending machine much easier from a side approach as opposed from a front approach.

Thirdly, student final design drawing solutions were more balanced and thought out because students were able to incorporate into their final solutions actual client interview information, class discussions and observation findings. Furthermore, students were able to experience firsthand different world perspectives working with the elderly and disabled individuals, which allowed students' design solutions have a greater breadth and meaning. Interior environment solutions gained in meaning because the solutions were done to improve a person's quality of life.

Fourth, students recognized their own short comings toward how their perceived individuals with physical limitations and altered their preconceived world views toward disability after they had experienced the various empathy exercises in class. Through this empathy recognition, students became better designers and gained an awareness of how interior environments silently emanate or provide subtle, direct visual cues that discourage disabled individuals and elderly from using the space. Therefore, empathy produced better designers and better prepared to address the program needs of a very diverse American population upon graduation, particularly the growing numbers of older American adults.

The findings suggest that empathy is fostered through the combination of experiences with elderly and disabled persons, observing the living conditions and exploration of environmental issues affecting how people use interiors spaces. Through this process, students develop a richer and deeper understanding of clients and more meaningful design problem solutions. With the number of older adults predicted to grow at a large pace for the next several decades it is important that interior design educators and researchers seek further research in how empathy can play a role in the scholarship of teaching and learning in higher education. Doing so will improve the preparedness of interior design students entering service-oriented industries. Furthermore, the findings suggest that it would behoove interior design educators to further research and incorporate empathy exercises into the curriculum so that students are not only prepared to work with diverse clients upon graduation, but also diverse classmates and future co-workers at the firms they decide to work for as well as become designers that view all phases and elements of design.

Although this research study brought forth how useful empathy can be as a learning tool for interior design students, the research study does have two limitations that need to be expressed. The first limitation is the small number of participants, while the second limitation pertains to the study's focus on one area of study - interior design. With that said the research study's focus on empathy as a learning tool is a concept that can be carried to other disciplines, specifically those that are service oriented and deal with diverse populations, such as healthcare and education. With the growing number of older American adults living longer and the global connectivity of nations growing every day through the use of social media and technology future empathy research could focus on the education of healthcare and public health workers. Additionally, with corporations tied to global markets it would behoove researchers to explore the role that empathy may play with team building and business. This is particularly an important issue that should be addressed by companies that conduct business overseas or are involved with varies industries or disciplines. Lastly, this research study suggests that for empathy to be successful as a learning tool student need to walk the talk they learn in the classroom.

\section{References}

American Society of Interior Designers. (2014). Interior design outlook 2014 and state of the industry report. Washington, D.C.: American Society of Interior Designers.

Bakker, A., \& Demerouti, E. (2009). The crossover of work engagement between working couples - Acloser look at the role of empathy. Journal of Managerial Psychology, 23(3), 220-236. https://doi.org/10.1108/02683940910939313

Batson, C. D., Turk, C. L., Shaw, L. L., \& Klein, T. R. (1995). Information function of empathic emotion: Learning that we value the other's welfare. Journal of Personality and Social Psychology, 68(2), 300-313. https://doi.org/10.1037/0022-3514.68.2.300

Batson, P., Harmon-Jones, I., Mitchener, B. K., \& Highberger (1997). Empathy and Attitudes: Can Feeling for a Member of a Stigmatized Group Improve Feelings Toward the Group? Journal of Personality and Social Psychology, 72(1), 105-118. https://doi.org/10.1037/0022-3514.72.1.105

Grant, L. (2014). Hearts and minds: Aspects of empathy and wellbeing in social work students. Social Work Education, 33(3), 338-352. https://doi.org/10.1080/02615479.2013.805191

Jacques, M. E., Linkowski, D. C., \& Sieka, D. C. (1970). Cultural attitudes toward disability: Denmark, Greece, and the United States. International Journal of Social Psychology, 16(1), 54-62. 
https://doi.org/10.1177/002076407001600106

Omdahl, B. L. (1995). Cognitive appraisal, emotion, and empathy. Mahwah, NJ: Lawrence Erlbaum Associates, Inc.

Ridley, C. R., \& Lingle, D. C. (1996). Cultural empathy in multicultural counseling: A multidimensional process. In P.B. Pedersen, J. G. Draguns, W. J. Lonner, J. E. Trimple (Eds.), Counseling across cultures (4 ${ }^{\text {th }}$ ed., pp. 21-46). Thousand Oaks, CA: Sage.

Rosenthal, R. (1977). The PONS test measuring sensitivity to nonverbal cues. In P. McReynolds (Ed.), Advances in psychological assessment (pp. 179-221). San Francisco, CA: Jossey-Bass.

Strayer, J. (1987). Affective and cognitive perspectives on empathy. In N. Eisenberg \& J. Strayer (Eds.), Empathy and its development (pp. 218-244). New York, NY: Cambridge University Press.

Tervo, R. C., Azuma, S., Palmer, G., \& Redinius, P. (2002). Medical students' attitudes toward persons with disability: A comparative study. Arch Physicians Medical Rehabilitation, 83(11), 1537-1542. https://doi.org/10.1053/apmr.2002.34620

Thomas, J., \& McDonagh, D. (2013). Empathetic design: Research strategies. Australasian Medical Journal, 6(1), 1-6. https://doi.org/10.4066/AMJ.2013.1575

U.S. Census Bureau. (2016). Fact sheet on the elderly population. Retrieved from www.census.gov/populations/www/pop-profile/elderpop.html

Wang, Y. W., Davidson, M. M., Yakushko, O. F., Savoy, H. B., Tan, J. A., \& Bleier, J. K. (2003). The Scale of Ethnocultural Empathy: Development, validation, and reliability. Journal of Counseling Psychology, 50(2), 221-234. https://doi.org/10.1037/0022-0167.50.2.221

Yuker, H. E., Block J. R., \& Young J. H. (1970). The measurement of attitudes towards disabled persons. New York, NY: Human Resources Center, Mend Institute.

Yuker, H. E., Block, J. R., \& Campbell, W. J. (1960). A scale to measure attitudes toward disabled persons. Human Resources Studies (Study No. 5). Albertson, NY: Columbia University.

\section{Copyrights}

Copyright for this article is retained by the author(s), with first publication rights granted to the journal.

This is an open-access article distributed under the terms and conditions of the Creative Commons Attribution license which permits unrestricted use, distribution, and reproduction in any medium, provided the original work is properly cited. 